\title{
Reconsidering the rigour-relevance gap: the need for contextualised research in risk societies
}

Research Article

\author{
Robert J. Galavan ${ }^{1 *}$, Denis Harrington² and Felicity Kelliher \\ ${ }^{1}$ School of Business, Maynooth University, Ireland \\ 2Waterford Institute of Technology, Ireland
}

\begin{abstract}
This paper addresses the debate on rigour and relevance in management research to identify barriers to progress and identify the challenges and opportunities in moving forward. We identify strong calls from both North American and European literatures for a move to close this gap. It has, however, been 20 years since Hambrick asked scholars 'What if the academy actually mattered?' during his Presidential address to the Academy of Management. Despite both the time and the consistency of calls, there has been only modest progress in closing this rigour-relevance gap. We argue that this is not because of any lack of willingness or capacity but is shaped by systemic issues. We find the narrative of the business school framed as either professional or social sciences a core issue. Each brings with them a tradition of different ontological perspectives and epistemological processes, protected by gatekeepers, which supports, even if unintentionally, the maintenance of the gap. We go on to discuss the challenge of management education and research in a postmodern context, the need to examine our conception of rigour, and to challenge the definition of management as a profession given its strategic win-lose orientation. We conclude with a discussion on the relationship between society and business and lay out the challenges ahead for richly contextualised scholarly work that may be defined as both rigorous and relevant.
\end{abstract}

Keywords: epistemology; management research; mode 2; ontology; rigour-relevance gap; risk society

(c) De Gruyter Open Sp. z 0.0 .

\section{THE RIGOUR-RELEVANCE DEBATE}

In his 1993 presidential address to the assembled faithful of the Academy of Management Hambrick posed the question, 'What if the academy actually mattered?' (1994: 11). This rhetorical question set his esteemed colleagues, world leading management scholars, in the category of perhaps rigorous knowledge workers, but definitely not relevant to their community of practice. One might presume that when Hambrick, a giant of his era with a record of citations that is the envy of most scholars and a field of work that has been defined by his contribution for 25 years, we would take note and act.

Three years later, Mowday (1997: 341) found it necessary to return to the theme in his presidential address referring to what has ultimately become a perennial challenge of being both rigorous and relevant management research. In 2002, Bartunek (2003: 203) had a dream for the academy where we work to make a difference and speak to tensions involving theory and practice. In 2005, Rousseau (2006) addressed the topic through the search for evidence based management to bridge the research-practice divide. While the language of the debate has modified in the post global financial crisis era, the core issue has remained. Tsui (2013), in her 2012 address on the need for compassion in business education, clearly relates the potential for business schools to do harm to the research-practice gap that has been widely discussed (Khurana, 2010; Pfeffer and Fong, 2002, 2004).

The European debate on the issue has had equal longevity and coverage, with the British Academy of Management leading a search in 1995 for the academic beast that could leap such future challenges as Pettigrew's (2001) double hurdle. What emerged was a debate closely aligned with the call for a transition from Mode 1 to Mode 2 forms of 
enquiry (Gibbons et al., 1994; Nowotny et al., 2001) most notably characterised by Tranfield and Starkey (1998) who argued that management research must take account of the fields ontology as a discipline of practice which aligns it more with engineering than pure science and lends itself to Mode 2 collaborative enquiry. Despite diversions towards Mode 1.5 (Huff, 2000) in recognition that Mode 1 and Mode 2 are not dichotic, the call for a move to Mode 2 was carried through to the influential Starkey and Madan report (2001), albeit with the caution that it was not Mode 2 at the expense of Mode 1. We were then offered the tantalising thought of moving to Mode 3 (Starkey, 2001).

Despite the attention brought to the issue by such eminent scholars, the conversation has stubbornly remained in this conceptual phase. Perhaps because we are too wedded to our traditional approaches or perhaps we have not found the means of articulating the method needed to match our emerging theory. One attempt to move the theory towards a method of investigation is provided by MacLean et al. (2002) with the first comprehensive articulation of the five key features of mode 2 enquiry in what they call their 5 mode 2 framework and it is from this point that we try to take up the challenge to transcend Mode 1 in our teaching and research (Kelliher et al., 2010). Whether we have reached mode 1.5, Mode 2, Mode 3, Hodgkinson's Pragmatic Science (Hodgkinson et al., 2001: S42) or Pettigrew's double hurdle (2001) is unclear. The intention of our paper is not to propose a neatly packaged Mode 1.75 approach or a lofty Mode 4, but rather it is to explore the struggle, reaffirm the need, and point to the opportunities hidden within the rigour-relevance debate.

We approach the task in three phases. First, to explore why so little progress has been made? If there is, at least apparent energy and enthusiasm for movement, what barriers are slowing or stalling progress. Second, what is considered to be managerially relevant research. This question also comes with an inherent second order challenge, and that is, who gets to decide what is relevant research? Closely coupled is the issue of what we consider to be rigour and how this is evolving? Third, we discuss the challenges for the future.

\section{WHY SO LITTLE PROGRESS?}

We ask the question of little progress in recognition that there has been some progress or at least debate, engagement, and in some quarters enthusiasm to change the way we conduct our research and ultimately influence practice and policy.

In its simplest form the strategic question we are addressing is knowing where it is we want to go. If there is a rigour-relevance gap, then it might appear that closing the gap is the straightforward strategic objective. But before moving to close the gap we should consider if closing the gap is indeed what we (the community of management scholars) want to do; if closing the gap is our desire then we must fully understand the nature of the relevance and the rigour we seek to connect.

The first consideration in this regard should be who or perhaps what we (Business/Management Schools) are. Starkey and Tempest (2008) describe the two dominant narratives of the business school as professional and social sciences. Regardless of which of the narratives we acknowledge, we must do so in the context of the extremely competitive market in which business schools operate. Creating a competitive advantage in this context is a necessity for a business schools survival. The social science school creates advantage from its deeply held stocks of disciplinary knowledge which are difficult to replicate. This knowledge is dominated, particularly in the US, by economics and its close relative finance. Both these disciplines are in turn dominated by a positivist philosophy characterised by an ontology of discrete and objective elements. In this epistemology, knowledge is accessed through the identification of regularities that are observed, eschewing any value in underlying concepts, such as motivations, which cannot be directly observed. The objective of the social science in this context is to cure its 'physics envy' through the creation of knowledge that is both explanatory and predictive, leading to the description of the world as it is or should be. Relevance in this context has become the ability to provide normative causal models that explain profitability and so shape resource allocation decisions. This approach has been particular useful to those who manage at the level of markets or populations, where the nuance of the individual is often difficult to discern. In this narrative relevance is through positivist theory, described primarily via the medium of economics and finance or their derivatives, that leads directly or indirectly to the causal explanation of firm performance. We are in this case seekers of truth or right.

The professional narrative or that of practice is, according to Starkey and Tempest (2008), closer to the medical or law school model with the vocational role of training practitioner. A defining characteristic of a profession in this context is its relationship with society (Khurana, 2007) and certainly the medical profession demonstrates the characteristic of an ethic focused on the public good. Whether this can translate to a management profession is 
unclear. Strategic management has focused on the development of approaches for the creation of competitive advantage (Porter, 1985). This competitive advantage has in its sights not just value creation, which could form the basis of the social ethic, but also value capture. When value capture and value creation occur together it creates a mutually fulfilling cycle in which businesses are repaid for the value created. A business good is created from a social good and the market is seen to be an effective tool of society. However, the strategic objective of competitive advantage is explicitly to create a market failure - a market failure driven by the monopolistic capability of a firm which is then leveraged to capture a disproportionate portion of the value or profit. When the focus of a firm is value capture ahead of or even instead of value creation, the societal compact is broken and the concept of a profession fails. In business therefore, doing relatively better is the standard of performance. If the medical profession were to take this approach it would see doctors not trying to improve the lot of patients in general, but individual doctors trying to improve the lot of their personal patients even to the detriment of other patients. While doctors clearly compete with each other they don't try to harm or kill each others patients to prove they are relatively better doctors. The ethic of the profession is an overriding concern for the patients well-being, above that of the doctor (Cassel and Brennan, 2007), thus determining a requirement for system level value creation over individual value capture. Without a similar societal compact it is difficult to argue for management as a profession. Competitive advantage in a professional business school narrative is therefore achieved through the development of practices which capture value but do not necessarily create value. We are in this case tools of business in search of what works for business.

The success of the social science narrative in influencing practice and in particular policy, has largely been confined to narrow fields of economics and finance. Science in this context is positivist science and despite the efforts of, in particular, sociology and psychology to influence business, it has not occurred with anything like the same level of success. This has resulted in research that is rigorous in the positivist paradigm, but lacks broad relevance because of the narrow dimension that it addresses and the lens that it makes available. The dominant we in this social science narrative might espouse the desire to close the relevance gap but this can not be achieved through positivist science alone and so any expressed desire to close the gap is little more than rhetoric.

The success of the professional narrative in influencing practice has been driven by the extensive use of case studies shaped by Harvard Business School (McNair and Hersum, 1954), the rise of management gurus (Lauer, 2008), and the acceptance, possible adoration, of practitioners texts such as those by Jack Welch the former CEO of General Electric (Welch, 2005). In this narrative, fads and fashions across a broad spectrum are adopted by practice because of their contagion rather than their efficacy (Williams, 2004) and perceived relevance takes over from rigour. The dominant we in the professional narrative serves business and competes for acceptance and favour as a measure of relevance. What if then, through the application of rigour, we identify knowledge that is not favoured? What if, through the application of a professional ethic we benefit society, but limit the profit potential of individual organisations? If added rigour leads to answers that business does not like and will not favour, do those in the professional narrative lose the competitive advantage of relevance? If as we suspect advantage would be lost, then the desire of a school in the professional narratives to be more rigorous can be little more than rhetoric and the concept of a management profession is in peril.

The two dominant narratives in business schools, the professionally relevant and the scientifically rigorous, therefore have every reason to remain focused on their competitive advantage, and little reason to change. Unless the reward systems really change, there is little impetus for change and the rhetoric of leaping dual hurdles will remain. The system of gatekeepers (editors and senior faculty) in the domain of the rigorous and funding streams from business in the domain of the relevant will ensure the status quo.

In 1963, the Dean of the Graduate School of Business in Michigan State University, Seeley (1963) noted that, in the face of uncertainty, the major emphasis for the business school should be a focus on theory as timeless tools rather than the ephemeral subject matter that describes business practices. In this light we, as management educators are there to train the minds that will generate and regenerate the practices of business, not to provide descriptions of normative practices. We (the majority of Business Schools) have, perhaps somewhat regrettably, not lived up to Seeley's challenge. We have provided only limited theoretical perspectives that are of use to practice and it is claimed that our vocational efforts have produced 'critters with lopsided brains, icy hearts, and shrunken souls' (Leavitt, 1989). Unless the strategic narrative of the professional and the social science perspectives changes, there is little hope of improvement.

The lack of progress towards rigour and relevance can therefore be explained, in part at least, through recognising that while we may have individuals that want to change the narratives, the systems we have developed provide no 
effective means of leveraging that change. Even if we did, as a system, want to change, the lack of a method to match the ambition is an impediment. Management scholars, regardless of their enthusiasm for change, are faced with the shackles of the systems within which they operate and a lack of tools with which they can try to break free.

\section{WHAT IS RIGOUR AND RELEVANCE?}

The Carnegie (Pierson, 1959) and Ford (Gordon and Howell, 1959) foundations reports of 1959 berated business schools for their focus on teaching from practice (one of the conceptions of relevance) rather than theory (rigour). Driven by the impetus of a stick, in the form of a poor report card, and a carrot, in the form of funding from the foundations, American business schools began to change. The result is a social science narrative of the business school that has embraced a lopsidedly macro positivist philosophy of science, delivering rigour through quantitative method to the almost complete exclusion of other methods. Credibility in this narrative derives from the acceptance of peers (in the natural sciences) that this is a scientific approach and its rigour is validated against this internal bench mark. Krugman elegantly captured this sentiment when he explained to his economics class that 'If you are a good economist' you are 'reborn as a physicist; if you are an evil, wicked economist, you are reborn as a sociologist' (1994: xi). One wonders what extreme form of deviance one must display to be reborn as a management scholar.

We do not mean to argue that in any way deductive reasoning fails to add an important element to our decision making toolkit, but it is not a total solution. In our emerging postmodern landscape, it is becoming clear that the certainty we looked for at the altar of science (having eschewed religion) may not be available to us. Science in the 21st century is raising more questions than it is answering and there is a dawning recognition that in a quest for knowledge societies which were presumed to bring certainty, we have an emerging risk society (Nowotny et al., 2001) in which we must find creative, innovative and untested solutions. Indeed there are those who would argue that we must go beyond a focus on decision making, which even in its most general and pluralistic sense is too limited and that we must embrace other explanations such as sense making (Weick, 2001) as methods for progress in futures that are not only unforeseen, but perhaps unforeseeable.

The postmodern perspective challenges us to disengage from the notion of the grand or meta-narrative and to deal with the crisis that this brings upon the university institution (Lyotard, 1984). This crisis is the loss of a singular definition of rigour and requires movement to a place where reincarnation as a sociologist may not be seen as a wicked thing. Rather than seeking comfort in a singular truth, postmodernism requires us to embrace the plurality of truth through engagement with a diversity of perspectives, including contextualised ones, that contribute to knowledge. Nowotny et al. (2001) call for a contextualisation of research that recognises the interrelated role of science and society - in this narrative contextualisation is a general ambition of science rather than a pollutant.

Decontextualised science cannot provide the solution to the postmodern problem and Nowotny et al. (2001) identify that the evaluation of quality in research is no longer solely within the gift of a closed academic tribe. This brings with it great opportunity and great challenge. All stakeholders involved in research are not created equal or at least not the same and each bring different biases, objectives, skills and abilities to the process. In this world the quality of our scholarly work cannot be defined singularly in terms of the quantitative method which, while excellent in some contexts, provides limited value in others. If the rigour of our work is not defined in terms of its quality and fitness for purpose then we as researchers are subservient to the method. Claiming rigour on the basis of a well implemented method, even though the method is unsuited to the question, is akin to the medic claiming the operation was a success even though it was not the operation the patient required. Ignoring the question (refusing to treat the patient appropriately) because it does not suit our method, makes us slaves of our science and abandons all hope of a relationship with society that could infer we are a profession. If we have aspirations to be a profession, which we strongly believe is a must then our relevance must be defined in terms of its impact on society, via the medium of organisations and the economy.

\section{THE ROAD AHEAD}

The business institution became the dominant institution of our time, in large part because of its ability to encourage innovation that leads to developments and efficiencies in the delivery of products and latterly services for society. Its dominance has, however, in our view, been overplayed to the extent that in some ways societies and governments 
have come to serve the economy. While there is without doubt a reciprocal relationship, between government, society and economy, there is also a hierarchy that must recognise the primacy of society.

Even if we wished to retain the primacy of the economy (perhaps even in a belief that its methods better serve society than society sometimes serves itself), the recent turmoil in financial markets and the loss of trust between civil society and business leaders, in particular those in financial services will make it difficult to go back to the way it was before the financial crash (2008). As we move forward, rather than take the easy way and swing the pendulum from unfettered free market economics to nationalisation, we must find a third way where the primacy of society is protected and the powerful energy of free markets is maintained. The answer to our problems is not more government or freer markets, and neither is the answer somewhere between the two. Success is not a semi-rule bound economy, and an almost important society. We must rather use all of our energy to create new futures, new paradigms, and new narratives if we are to prosper in the 21st century. The global financial crisis is passing, but this should not result in a return to the way things were. The eggs have been broken and they cannot be unscrambled. Our emergence as a stronger society will depend on finding new ways to allow the economy to work in ways with which society can trust that the economy is there to improve society. At the same time, our knowledge society is creating a risk society which will make this goal even more elusive. These are the challenges of managerially relevant research and the aspirations to which our management and our profession should aim. These are the standards to which we will be held accountable and our success or failure will be the mark of 21 st century society.

These issues are as most management challenges are, challenges of the future. There are no examples and no theories that can give us certainty. We have no choice therefore, if we are to be relevant to managers and society, but to embrace a broader perspective of science. We must turn contextualisation, the pollutant of modern positivist science, into a strength in the postmodern perspective. Rather than rely solely on retrospective deduction, we must embrace reasoning that is inductive, abductive, and critical as we work with our communities to create new futures. This cannot be done in the abstract nor can it be done without proper recognition of temporal development. 'Life cannot be modelled, no matter how complex the algorithms or how large the database upon which the model draws' (Tiffany, 2009: 819) and so a tacit understanding of our evolving relationships with each other and our environment is essential. In a risk society where business institutions shape their context, rigour must infer the development of wisdom based on a meaningful understanding of what happened and why. This is by definition contextually embedded in its historical evolution. In a risk society, decontextualised knowledge of static phenomena provides no basis for a rigorous prediction. Difficult as it is we must, as scholars, find effective methods to serve us in the historically contextualised science of our still developing society. Our wisdom to accept a more pluralist definition of rigour can emerge from a recognition of our evolution. We have not, as Fukuyama (1989) suggested, reached the end of history, we have reached the point where we must recognise the potential for a rich understanding of contextualisation to enlighten our future.

\section{References}

Bartunek, J.M. (2003). 'A dream for the academy'. Academy of Management Review, 28, 198-203.

Cassel, C.K. and Brennan, T.E. (2007). 'Managing medical resources: Return to the commons?'. Journal of the American Medical Association, 2518-2521.

Fukuyama, F. (1989). 'The end of history?'. The National Interest, 16, 3-18.

Gibbons, M., Limoges, C., Nowotny, H., Schwartzman, S., Scott, P. and Trow, M. (1994). The New Production of Knowledge: The Dynamics of Science and Research in Contemporary Societies, London: Sage.

Gordon, R.A. and Howell, J.E. (1959). Higher Education for Business, NY: Columbia University Press.
Hambrick, D.C. (1994). 'What if the academy actually mattered?'. Academy of Management Review, 19, 11-16.

Hodgkinson, G.P., Herriot, P. and Anderson, N. (2001). 'Realigning the stakeholders in management research: Lessons from industrial, work and organizational psychology'. British Journal of Management, 12, S41.

Huff, A.S. (2000). 'Changes in organizational knowledge production'. Academy of Management Review, 25, 288-293.

Kelliher, F., Harrington, D. and Galavan, R. (2010). 'Spreading leader knowledge: Investigating a participatory mode of knowledge dissemination among management undergraduates'. Irish Journal of Management, 29, 107-125. 
Khurana, R. (2007). From Higher Aims to Hired Hands: The Social Transformation of American Business Schools and the Unfilled Promise of Management as a Profession, MJ: Princeton University Press.

Khurana, R. (2010). From Higher Aims to Hired Hands: The Social Transformation of American Business Schools and the Unfilled Promise of Management as a Profession, Princeton, NJ: Princeton University Press.

Krugman, P. (1994). Peddling Prosperity: Economic Sense and Nonsense in the Age of Diminished Expectations, NY: W.W. Norton \& Company.

Lauer, C. (2008). The Management Gurus, London: Penguin Books.

Leavitt, H.J. (1989). 'Educating out MBA's: On teaching what we haven't taught'. California Management Review, 31, 38-50.

Lyotard, J.F. (1984). The Postmodern Condition: A Report on Knowledge, UK: Manchester University Press.

MacLean, D., Macintosh, R. and Grant, S. (2002). 'Mode 2 management research'. British Journal of Management, 13, 189-207.

McNair, M.P. and Hersum, A.C. (1954). The Case Method at the Harvard Business School, NY: McGraw-Hill.

Mowday, R.T. (1997). 'Reaffirming our scholarly values'. Academy of Management Review, 22, 335-345.

Nowotny, H., Scott, P. and Gibbons, M. (2001). Rethinking Science: Knowledge and the Public in the Age of Uncertainty, Oxford: Polity Press.

Pettigrew, A.M. (2001). 'Management research after modernism'. British Journal of Management, 12, S61.

Pfeffer, J. and Fong, C.T. (2002). 'The end of business schools? Less success than meets the eye'. Academy of Management Learning \& Education, 1, 78-95.

Pfeffer, J. and Fong, C.T. (2004). 'The business school 'business': Some lessons from the US experience'. Journal of Management Studies, 41, 1501-1520.

Pierson, F.C. (1959). The Education of American
Businessmen: A Study of University-College Programmes in Business Administration, NY: McGraw-Hill.

Porter, M.E. (1985). Competitive Advantage: Creating and Sustaining Superior Performance, NY: Free Press.

Rousseau, D.M. (2006). 'Is there such a thing as 'Evidence Based Management'?'. Academy of Management Review, 31, 256-269.

Seeley, A.L. (1963). 'The role of business schools in a changing environment'. Accounting Review, 38, 302-309.

Starkey, K. (2001). 'In defence of modes one, two and three: A response'. British Journal of Management, $12, \mathrm{~s} 77$.

Starkey, K. and Madan, P. (2001). 'Bridging the relevance gap: Aligning stakeholders in the future of management research'. British Journal of Management, 12, S3.

Starkey, K. and Tempest, S. (2008). 'A clear sense of purpose? The evolving role of the business school'. Journal of Management Development, 27, 379-390.

Tiffany, P. (2009). 'Does history matter in business?'. Enterprise and Society, 10, 816-830.

Tranfield, D. and Starkey, K. (1998). 'The nature, social organization and promotion of management research: Towards policy'. British Journal of Management, 9, 341.

Tsui, A.S. (2013). 'On compassion and scholarship: Why should we care?'. The Academy of Management Review, 38,167-180.

Weick, K.E. (2001). 'Gapping the relevance bridge: Fashions meet fundamentals in management research'. British Journal of Management, 12, S71.

Welch, J.W.S. (2005). Winning, NY: Harper Business.

Williams, R. (2004). 'Management fashions and fads: Understanding the role of consultants and managers in the evolution of ideas'. Management Decision, 42, 769-780. 